\title{
Modelling and optimization of drying rate and quality parameters of foam mat dried mango powder
}

\author{
Christiana Alami Adamade ${ }^{1}$ and Joshua Olanrewaju Olaoye ${ }^{2, *}$ \\ ${ }^{1}$ Department of Agro- Industrial Development and Extension, National Centre for Agricultural Mechanization (NCAM), \\ Ilorin, Kwara State, Nigeria. \\ 2 Department of Agricultural and Biosystems Engineering, University of Ilorin, Kwara State. Nigeria.
}

Global Journal of Engineering and Technology Advances, 2021, 08(03), 032-037

Publication history: Received on 28 July 2021; revised on 04 September 2021; accepted on 06 September 2021

Article DOI: https://doi.org/10.30574/gjeta.2021.8.3.0124

\begin{abstract}
A study on modeling and optimization of foam mat drying of ripe mango was carried out, three levels of whipping durations ( $5 \mathrm{~min}, 10 \mathrm{~min}$ and $15 \mathrm{~min}$, three levels of Egg white albumen powder concentrations as foaming agent (6\% $(\mathrm{w} / \mathrm{w}), 12 \%(\mathrm{w} / \mathrm{w})$ and $18 \%(\mathrm{w} / \mathrm{w})$ ), three levels of Xanthan gum concentration as foam stabilizing agent $(0.02 \%, 0.04 \%$ and $0.06 \%$ )and three levels of air drying temperature $\left(50^{\circ} \mathrm{C}, 60^{\circ} \mathrm{C}\right.$ and $\left.70{ }^{\circ} \mathrm{C}\right)$ as input parameters were used. Design Expert 6.06 version was used to design the experiment in order to get all possible combinations of durations and concentrations. After washing and deseeding all samples of fresh mango, the pulp was foamed using egg white powder and liquid as foaming agent, the was stabilized by using xantham gum at different concentrations. The foamed products were all dried at $50^{\circ} \mathrm{C}, 60^{\circ} \mathrm{C}$ and $70^{\circ} \mathrm{C}$ respectively in an instrumented cabinet dryer. The following output parameters were modeled and optimized with Design Expert 6.0.6 version: drying rate, vitamin C, beta carotene, crude protein, crude fibre, fat content, ash content, moisture content, carbohydrate and total soluble sugar. Ten (10) model equations, one for each of the output parameters were developed, and checked for adequacy and validity. All developed model equations were found to present functional relationships between input and output parameters. Hence, all developed model equations can be used as reliable tools for estimating, predicting and conducting analysis of the process. Best optimized results were selected base on the one that is most desirable. One of the ways of explaining optimization is that, it is the process of getting the values of input parameters that will either maximize or minimize the output parameters, drying rate (maximized), vitamin C (maximized), beta carotene (maximized), crude protein (maximized), crude fibre (maximized), fat (maximized), ash content (maximized), moisture content (minimized), carbohydrate (maximized), total soluble sugar (maximized) and moisture ratio (minimized).
\end{abstract}

Keywords: Modeling; Optimization; Foam mat drying; Quality; Mango

\section{Introduction}

Mango (Mangifera Julie) is one of the most important and choicest of all tropical fruits. It is rightly referred to as the 'King of Fruits' because of its excellent flavor, delicious taste and higher nutritional value (1). Mango occupies the first position in tropics as being enjoyed by all in temperate countries and being a highly perishable crop inflict greater setback as in storage and transportation. The problem of storage facilities and poor transportation created a wide gap between total production and consumption leading to post harvest losses (1).

Foam-mat drying is a technique that involves incorporation of foaming agent into liquids or semi-liquid with adequate whipping to form stable and stiff foam, and subsequently dehydrated by air drying (2). Foam mat drying leads to

${ }^{*}$ Corresponding author: Olaoye JO

Department of Agricultural and Biosystems Engineering, University of Ilorin.

Copyright (C) 2021 Author(s) retain the copyright of this article. This article is published under the terms of the Creative Commons Attribution Liscense 4.0. 
increase of surface area, faster drying rate and considerable decrease in drying time and drying temperature; as well improve the sensory, nutritional and functional properties of the product. In addition, the foam mat dried products are highly stable against deteriorative microbial, chemical and biochemical reactions. The shorter drying time generated not only reduces the dryer load but also increases the dryer throughput by 32 and $22 \%$ for foamed material (3).

Modeling is the construction of physical, conceptual or mathematical simulation of the real world events (4). It is also the process of developing equations or expressions that show functional relationship between dependent variables (outputs or responses) and independent variables (inputs or conditions of operation). Some examples of model types are: analytical models, statistical models, empirical models, stochastic models, mathematical models, mechanistic models, process model, block models and so on. Model equations are tools for making decision, prediction, estimation, forecasting and analyzing specific systems with the aim of having a better understanding of such systems. Optimization is the process of finding actions that maximize or minimize the value of an object function (www.swlearning.com). Some of the techniques of optimization are differential calculus, linear programming and sequential technique and simultaneous technique. All these techniques of modeling and optimization are now available in form of software packages for computer systems. (5), (6), (7) developed models equations and optimize the osmotic dehydration and drying of onion, red bell pepper and carrot slices respectively. (8) carried out the optimization of the drying process of onion slices in a vacuum dryer; with temperature range of $50^{\circ} \mathrm{C}-70{ }^{\circ} \mathrm{C}$, onion slices of $1-5 \mathrm{~mm}$ thickness, and pre treating in solution.

Modeling and optimization of the processes of foam mat drying for the purpose of getting functional relationships between input and output parameters and getting values of input parameters that will either maximize or minimize the output parameters(responses) are necessary. This will ensure better understanding of the process which can be used as tools for further research and industrial production of dried mango powder. Therefore the objectives of this study were to develop and validate model equations for processing fresh mango to foam mat dried mango powder and to carry out optimization of the process with the use of 6.0.6 version of Design Expert Computer Software.

\section{Material and methods}

\subsection{Experimental Equipment and Materials}

The following equipment and materials were used for the experiment: a fabricated cabinet dryer, electronic weighing balance (OHAUS CL Series, Model CL 201, China), stop watch(Nokia X2-01), containers, stainless steel tray and knife, foil paper, spatula and hand gloves, Egg white powder/liquid, Xanthan gum, distil water, fresh ripe mango.

\subsection{Experimental Design}

To design the experiment, Design Expert 6.0.6 version Computer Software was used. Response Surface Methodology (RSM) under Central Composite Design was used. Three levels of whipping durations (5 min, $10 \mathrm{~min}$ and $15 \mathrm{~min}$, three levels of Egg white albumen concentrations as foaming agent (6\% (w/w), 12\%(w/w) and 18\% (w/w)), three levels of Xanthan gum concentration as foam stabilizing agent $(0.02 \%, 0.04 \%$ and $0.06 \%)$ and three levels of air-drying temperature $\left(50^{\circ} \mathrm{C}, 60^{\circ} \mathrm{C}\right.$ and $\left.70^{\circ} \mathrm{C}\right)$ were introduced into the experimental design interface of the software to generate all combinations for the drying operative conditions.

\subsection{Experimental Procedure}

Ripe Julie mangoes were procured from a commodity market in Ilorin, Kwara State, Nigeria. The foaming and drying experiments were performed at the Food Engineering Laboratory, National Centre for Agricultural Mechanization Idofian, Kwara State, Nigeria. Fresh Mango fruits were sorted, washed, peeled and washed in order to get better quality for the experiment. Pulped mango flesh of $100 \mathrm{~g}$ was introduced into the whipped egg white concentrations for each type at different levels. At the end of the whipping process, uniform stable foam with increased foam volume resulting into foam expansion was produced. The products were then dried at three levels of drying temperature and constant air velocity of $2 \mathrm{~m} / \mathrm{s}$. Change in mass was monitored every minute using aluminum load cell until the end of drying which lasted for minimum of 5hours and maximum of 7hours depending on temperature of drying. After drying to average moisture content ranging from $4.29-5.84 \%$ (wb), all the dried samples were arranged inside the desiccator and were later taken for nutritional analysis.

\subsection{Measured Parameters}

Drying rate was estimated using the equation in (9). Quality parameters were determined using (10) standard. Data Analysis All the data for all the 10 outputs (drying rate, vitamin C, crude protein, crude fibre, fat content, ash content, 
beta carotene, moisture content, total soluble sugar and carbohydrate) obtained were introduced into the experiment table.

\subsection{Data Analysis}

The data generated were analyzed following the standard procedures of the software for RSM in order to get welldesigned and dependable relationships that relate the two process conditions with each of the output parameter. Optimization of the process was done with the software.

\section{Results and discussion}

\subsection{Developed model equations}

Below are the 10 developed model equations that gave functional relationship between input variables (osmotic process concentration and osmotic process duration) and output variables (drying rate, vitamin $\mathrm{C}$, crude protein, crude fibre, fat content, ash content, beta carotene, carbohydrate, total soluble sugar and moisture content).

$$
\begin{aligned}
& \text { Drying Rate }(\mathrm{g} / \mathrm{hr})=84.36+0.65 \mathrm{~A}+175.32 \mathrm{~B}-2.58 \mathrm{D}+0.05 \mathrm{~A}^{2}+0.02 \mathrm{D}^{2}-14.62 \mathrm{AB}-0.02 \mathrm{AD} ;\left(\mathrm{R}^{2}(\mathrm{adj})=0.7797\right) \ldots .(1) \\
& \text { Carbohydrate }(\%)=84.39-0.56 \mathrm{~A}-0.12 \mathrm{D}+9.25 \times 10^{-3} \mathrm{AD} ;\left(\mathrm{R}^{2}(\operatorname{adj})=0.7001\right) \\
& \text { Protein content }(\%)=5.26+17.73 B+0.05 C-1.54 B C ;\left(R^{2}(\operatorname{adj})=0.7124\right) \\
& \text { Fibre content }(\%)=10.41-0.30 \mathrm{C}+0.01 \mathrm{C}^{2} ;\left(\mathrm{R}^{2}(\mathrm{adj})=0.7001\right) \\
& \text { Fat content }(\%)=0.03+8.99 B+0.085 C-4.24 \times 10-3 C^{2}-2.04 B C+0.10 B C^{2} ;\left(R^{2}(\operatorname{adj})=0.8739\right)
\end{aligned}
$$

Beta carotene $(\mathrm{mg} / 100 \mathrm{~g})=-17.91-0.38 \mathrm{~A}+138.13 \mathrm{~B}+2.26 \mathrm{C}+0.76 \mathrm{D}+0.02 \mathrm{~A}^{2}-5.52 \times 10^{-2} \mathrm{D}^{2}+0.03 \mathrm{AC}-13.74 \mathrm{BC}-2.17 \mathrm{BD}$ $-0.07 C D-1.09 \times 10^{-3} A^{2} \mathrm{C}+5.08 \times 10^{-4} C^{2}+0.22 B C D ;\left(R^{2}(\operatorname{adj})=0.7132\right)$

\subsection{Model Adequacy Checking}

The developed model equations were adequately checked with some specific statistics stated in Table 1 . From the table, and values of coefficient of multiple determination and adjust coefficient of multiple determination were of close values; this defined the total variability of all models developed. According to (11), relatively close values of the statistics is an indication that models developed are good and in agreement with the results (6). (12) stated that neither high nor low values determine that a model is good or bad. Another statistics that guarantee goodness of fit is the coefficient of variation (C.V) which is the unexplained variances in the data given by the standard error of models. (11) stated that for all the models developed, small values of C.V were obtained and selected which is an indication that the fit is good. Also another parameter is the probability values of "lack of fit" this must not be significant at P. The reason for this is that, it is expected that a fitness of model should be achieved. In a different development, the probability values of models developed must be significant at $\mathrm{P}$ for them to tend towards being accepted as good. From Table 1, the P-values (probability values) of "lack of fit" are not significant for drying rate (0.07), vitamin C (0.32), beta carotene (0.24), fat (0.93), crude fibre (0.3643), ash (0.1), crude protein (0.83), carbohydrate (0.41), total soluble sugar (0.65) and moisture content (0.82). Also, the P-values for models are significant for drying rate (0.01), vitamin C $(0.02)$, beta carotene $(0.02)$, fat (0.03), crude fibre (0.05), ash (0.04), crude protein (0.04), carbohydrate (0.04), total soluble sugar (0.04) and moisture content (0.04). Lastly, for models to be accepted as good ones and serve their intended purposes, the value of 
adequate precision must be greater than 4 (13). All the values of adequate precision in Table 1 are greater than 4 . Therefore, it can be concluded that all the models developed are adequate and can be used to relate process input to process output. Hence they can be used for estimation, prediction and analysis of the process.

Table 1 Regression Statistics for Checking Adequacy of Model Equation using Egg Albumen Powder

\begin{tabular}{|l|l|l|l|l|l|c|c|c|}
\hline $\begin{array}{l}\text { Regression } \\
\text { Statistics }\end{array}$ & $\mathbf{R}^{2}$ & $\mathbf{R}^{\mathbf{2}}$ Adj & $\begin{array}{l}\text { Average of } \\
\text { Residuals }\end{array}$ & $\begin{array}{l}\text { Model P- } \\
\text { value }\end{array}$ & $\begin{array}{l}\text { Adequate } \\
\text { Precision }\end{array}$ & $\begin{array}{l}\text { Coefficient } \\
\text { of Variation }\end{array}$ & $\begin{array}{l}\text { P } \\
\text { Lack of fit }\end{array}$ & $\begin{array}{l}\text { Standard } \\
\text { Error }\end{array}$ \\
\hline Drying Rate (g/hr) & 0.7925 & 0.7797 & $-1.26 \mathrm{E}-14$ & 0.01 & 9.07 & 22.98 & 0.07 & 0.05 \\
\hline $\begin{array}{l}\text { Beta Carotene } \\
\text { (mg/100g) }\end{array}$ & 0.7363 & 0.7132 & $-6.34 \mathrm{E}-15$ & 0.02 & 6.91 & 7.66 & 0.24 & 0.01 \\
\hline $\begin{array}{l}\text { Vitamin } \\
\text { (mg/100g) }\end{array}$ & 0.6873 & 0.6414 & $-2.16 \mathrm{E}-14$ & 0.02 & 5.01 & 23.83 & 0.32 & 0.04 \\
\hline Ash (\%) & 0.8870 & 0.8419 & $-3.72 \mathrm{E}-15$ & 0.04 & 5.91 & 14.81 & 0.1 & 0.01 \\
\hline Protein (\%) & 0.7406 & 0.7124 & $-7.77 \mathrm{E}-15$ & 0.04 & 4.75 & 8.84 & 0.83 & 0.03 \\
\hline Fat (\%) & 0.8942 & 0.8751 & $-5.97 \mathrm{E}-16$ & 0.03 & 8.78 & 14.39 & 0.93 & 0.01 \\
\hline Fibre (\%) & 0.7211 & 0.7001 & $-9.93 \mathrm{E}-15$ & 0.05 & 7.83 & 8.26 & 0.79 & 0.01 \\
\hline Carbohydrate (\%) & 0.7231 & 0.7001 & $-1.21 \mathrm{E}-13$ & 0.04 & 4.29 & 1.89 & 0.41 & 0.01 \\
\hline $\begin{array}{l}\text { Total Soluble Sugar } \\
\text { (\%) }\end{array}$ & 0.8293 & 0.7944 & $-1.75 \mathrm{E}-14$ & 0.04 & 4.95 & 7.42 & 0.65 & 0.02 \\
\hline $\begin{array}{l}\text { Moisture content } \\
\text { (\%) }\end{array}$ & 0.7762 & 0.7428 & $-1.15 \mathrm{E}-14$ & 0.04 & 6.62 & 23.30 & 0.82 & 0.01 \\
\hline
\end{tabular}

\subsection{Optimization Result}

In simple terms, one of the ways of explaining optimization is that, it is the process of getting the values of input parameters that will either maximize or minimize the output parameters. Table 2 showed the optimization analysis. Goals were selected based on the significance of those outputs (drying rate, vitamin C (Vit. C), crude protein, crude fibre, fat, ash content, beta carotene, total soluble sugar, moisture content, moisture ratio, carbohydrate) in fresh ripe mango in relation to the study.

Table 2 Optimization results for Egg Albumen Powder

\begin{tabular}{|l|l|l|c|c|}
\hline Inputs & & Outputs (Responses) & Optimization Goal & Optimized Values \\
\hline $\mathrm{A}(\%)$ & $\mathrm{B}(\%)$ & Carbohydrate (\%) & Maximized & 76.50 \\
\hline 17.97 & 0.05 & Protein content (\%) & Maximized & 6.05 \\
\hline & & Fibre content (\%) & Maximized & 9.27 \\
\hline $\mathrm{B}(\mathrm{min})$ & $\mathrm{D}\left({ }^{\circ} \mathrm{C}\right)$ & Fat content $(\%)$ & Maximized & 0.41 \\
\hline 5.00 & 50.00 & Ash content $(\%)$ & Maximized & 3.10 \\
\hline & & Moisture content $(\% \mathrm{db})$ & Minimized & 4.59 \\
\hline & & Vitamin C $(\mathrm{mg} / 100 \mathrm{~g})$ & Maximized & 17.21 \\
\hline & & Beta Carotene $(\mathrm{mg} / 100 \mathrm{~g})$ & Maximized & 5.82 \\
\hline & & Moisture ratio & Minimized & 0.96 \\
\hline & & Drying rate $(\mathrm{g} / \mathrm{h})$ & Maximized & 15.93 \\
\hline & & Total soluble sugar $(\%)$ & Maximized & 18.61 \\
\hline
\end{tabular}


After the analysis, the software selected one best combinations of inputs(foaming agent concentration foam stabilizer concentration and whipping time) from 10 different optimization results for each output that best fulfilled the goals of the optimization (maximized or minimized. To optimize the drying rate of mangoes, 16.33\% of Egg Albumen Liquid as foaming agent, $0.03 \%$ of Xanthan gum as foam stabilizer, whipping time of 15 minutes and a drying temperature of $60.02^{\circ} \mathrm{C}$. This combination of factors will yield an optimum drying rate of $15.94 \mathrm{~g} / \mathrm{hr}$; Carbohydrate content of $73.67 \%$; Protein content of 6.55\%; Fibre content of 10.53\%; Fat content of $0.61 \%$; Ash content of $4.06 \%$; Moisture content of 4.91\%; Vitamin C content of 21.21mg/100g; Beta Carotene of 5.79mg/100g; Total soluble sugar of 19.53\%; Moisture ratio of 1.01 .

\section{Conclusion}

Operative drying conditions and foaming characteristics were the most significant factors that affect the drying process and model equations developed can be adequately used to predict operative drying conditions, foaming characteristics and quality attributes of mango powder. The most appropriate optimized conditions are EAL at foaming agent of $16.33 \%$; foam stabilizer of $0.03 \%$; whipping time of $15.00 \mathrm{~min}$; and Drying temperature of $60.02{ }^{\circ} \mathrm{C}$. It will help to predict the suitable drying conditions for mango by improving the drying process.

\section{Compliance with ethical standards}

\section{Acknowledgments}

I would like to express my gratitude to my supervisor, Prof J.0. Olaoye for his supervision, encouragement and excellent support throughout the research work. I acknowledge Dr M.M. Odewole for the assistance rendered in the development of the model equations and optimization. I appreciate all my colleagues for their kind gesture.

\section{Disclosure of conflict of interest}

No conflict of interest statement.

\section{References}

[1] Wilson RA, Kadam DM, Chadha S, Sharma M. Foam-Mat drying characteristics of Mango pulp. International Journal of Food Science and Nutrition Engineering. 2012; 2(4): 63- 68.

[2] Affandi N, Zzaman W, Yang TA, Easa AM. Production of Nigella sativa Beverage Powder under Foam - mat drying using Egg Albumen as a Foaming Agent. Beverages. 2017; 3(9): 1 - 15.

[3] Rajkumar P and Kailappan R (2006) Optimizing the process parameters for Foam Mat Drying of Totapuri Mango Pulp. Madras Agric J 93: 86-98.

[4] FA0. Faostat Database. Available on faostat.fao.org. Date accessed. April 2013.

[5] Alabi KP, Olaniyan AM, Odewole MM. Characteristics of onions under different process pretreatment and drying conditions.Journal of Food Processing and Technology. 2016; 7(2): 1000555.

[6] Odewole MM, Olaniyan AM. Empirical Modeling of Drying Rate and Qualities of Red Bell Pepper. LAP LAMBERT Academic Publishing, Germany.2015.

[7] Singh B, Panesar PS, Nanda V, Gupta AK, Kennedy JF. Application of Response Surface Methodology for the Osmotic Dehydration of Carrots. Journal of Food Process Engineering. 2006; 29: 592-614.

[8] Mitra J, Shrivastava SL, Rao PS. Process Optimization of Vacuum Drying of Onions Slices. Czech Journal of Food Science. 2011; 29: 586-594.

[9] Omodara MA. Effects of Some Drying Parameters on Drying Rate and Quality of African Catfish. Unpublished Thesis. Agricultural Engineering Department. University of Ilorin. Ilorin. Nigeria. 2011.

[10] AOAC (2003). Official Methods of Analysis. Association of Official Analytical Chemists, Washington D.C. 2020.

[11] David DS, Joachim W, Robbert PY. Essential Regression and Experimental Design for Chemists and Engineers. A manual for Regression Models. 1988; 12 - 88.

[12] Montgomery HC, Runger GC, Hubele NF. Engineering Statistics. John Wiley \& Sons, Inc. New York. $1998 ; 322$ 323. 
Global Journal of Engineering and Technology Advances, 2021, 08(03), 032-037

[13] Stat-Ease. Design-Expert Software. Version 6 User's Guide. Available on www.statase.com. 2000. 